\title{
The association between ownership concentration and payout behaviour: Evidence from South Africa
}

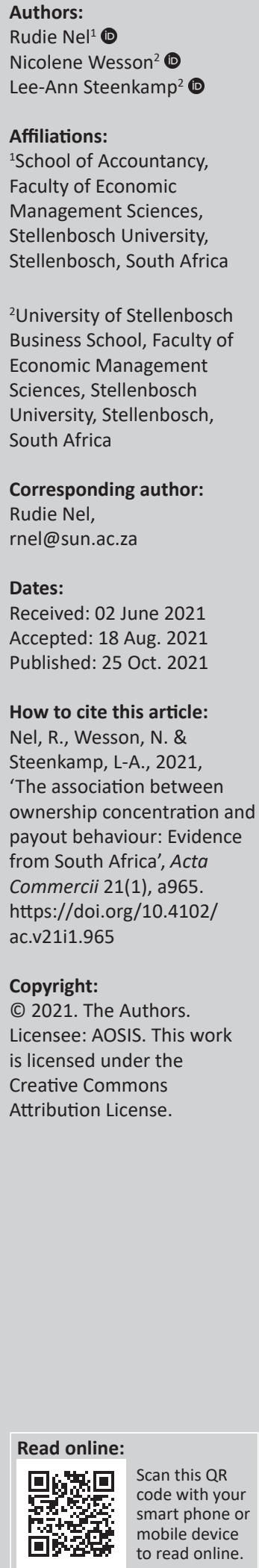

Orientation: The study investigated the association between ownership concentration and different payout methods of selected companies listed on the Johannesburg Stock Exchange (JSE) in South Africa for the financial reporting periods 2012 to 2019.

Research purpose: The research objective was to investigate whether payout behaviour differed when low and high ownership concentration was compared.

Motivation for the study: An understanding of the association between ownership concentration and payout policies is an important corporate governance aspect that could reveal the agency conflict between majority and minority shareholders. No previous South African empirical study has considered testing or investigating the two opposing agencybased hypotheses, namely the monitoring and rent extraction hypotheses, with reference to different payout methods.

Research design, approach, and method: An empirical research design was followed, which is descriptive in nature. Descriptive statistics and a mixed-model analysis of variance were employed to describe the different payout methods - that is ordinary dividends, special dividends, capital distributions, additional shares, general share repurchases, and specific share repurchases - employed by companies listed on the JSE based on a distinction between low and high ownership concentration.

Main findings: High ownership concentration was found to be associated with statistically significant lower ordinary dividends and capital distributions in support of the rent extraction hypothesis. Rent extraction highlights the agency conflict between majority and minority shareholders.

Practical/managerial implications: Findings of the present study revealed agency conflicts that may be informative to those charged with corporate governance to help them resolve agency conflict.

Contribution/value-add: This study is the first to consider the association between ownership concentration and payout behaviour in South Africa subsequent to the introduction of the dividends tax regime in 2012. The descriptive evidence submitted can serve as a basis for further explanatory research relating to ownership concentration and payout behaviour of companies.

Keywords: corporate governance; Herfindahl index; ownership concentration; payout methods; payout policies; rent extraction hypothesis.

\section{Introduction}

The ownership structure of a company, especially ownership concentration of large shareholders, is regarded as an important aspect of corporate governance that could influence company value (Faisal, Majid \& Sakir 2020). An analysis of the association between the largest shareholders of companies and payout behaviour is submitted as a contributor to a better understanding of dividend policy (Truong \& Heaney 2007). The increased use of payout methods other than dividends, especially share repurchases (Lazonick 2014), has led to a renewed interest in the motivation for different payout methods (Feito-Ruiz, Renneboog \& Vansteenkiste 2020; Liu, Chiou \& Yang 2014; Wesson et al. 2018). Investigating the association between ownership concentration and payout behaviour is accordingly warranted, particularly to explore its conceivable contribution as a factor of corporate governance and to improve an understanding of the payout policies.

Two opposing agency-based hypotheses, the monitoring hypothesis and rent extraction hypothesis, could explain the effect of ownership concentration on dividend policy (Harada \& Nguyen 2011). 
An investigation of the association between ownership concentration and dividend policy could underline the agency conflict between majority and minority shareholders in instances of rent extraction (Harada \& Nguyen 2011). A policy implication could flow from revealing agency conflict between shareholders if the supervisory responsibilities between shareholders, regulators, and other market participants are shared to prevent and reduce agency conflict (Faisal et al. 2020). An understanding of agency conflicts could accordingly aid government in determining laws and regulations that govern payout policies in instances of expropriation by the shareholders or management (Qopana 2018). Despite the importance of investigating the association between ownership concentration and payout policies, these aspects have not been considered in a South African context.

Prior empirical studies relating to companies listed on the Johannesburg Stock Exchange (JSE) in South Africa have investigated the determinants of dividends and share repurchases (Nyere \& Wesson 2019; Wesson et al. 2018), the relationship between corporate governance and dividend payout ratios (Mans-Kemp \& Viviers 2015), and the relationship between corporate governance board characteristics and dividend payout (Moloi, Nharo \& Hlobo 2021). No previous South African study could be identified which has provided empirical evidence in support of either the monitoring hypothesis or rent extraction hypothesis based on different payout methods. South African tax reform instituted since 2012, namely a change from a company-level tax to a shareholder-level tax on dividends, provides a distinct setting for empirical investigation of the association between ownership concentration and payout methods. Ownership concentration has been linked to the tax preference of shareholders (Booth \& Zhou 2017; Peyer \& Vermaelen 2016). The introduction of dividends tax in South Africa during 2012 resulted in dividends tax arbitrage arising for the first time, as only certain investors are exempt from dividends tax (Marcus \& Toerien 2014). The conflicting tax preference of different investors is further accentuated since the introduction of dividends tax during 2012 as a result of the differential tax on dividends and capital gains (Nel \& Wesson 2021). Payout methods other than dividends (such as capital distributions, additional shares, and share repurchases) could be subjected to capital gains tax instead of dividends tax, which could have informed the tax preference for such payout methods since 2012 ( $\mathrm{Nel} \&$ Wesson 2021). The new Companies Act (Republic of South Africa 2008) that came into effect in South Africa on 01 May 2011 is aimed at improving transparency, accountability, and the integrity of companies (Steyn 2018), and represents changes in the corporate governance environment in South Africa. Despite a wellrecognised and sophisticated corporate governance framework, South African companies have furthermore experienced corporate governance failures (e.g. the Steinhoff scandal) which have further attracted interest amongst academics and the public (Moloi et al. 2021). The South African context provides for a unique setting for further investigation since 2012 because of tax reform, changes in the corporate governance environment, and corporate governance failures.
The present study aimed to contribute to the literature in respect of the association between ownership concentration and payout policies. The objective of this study was to investigate whether payout behaviour of selected companies listed on the JSE in South Africa differed when low and high ownership concentration is compared. Based on the findings of this investigation, support for the monitoring hypothesis or the rent extraction hypothesis is submitted. In the sections which follow the literature review firstly positions the study within the dividend relevance theories; defines ownership concentration and payout methods as the two key concepts relevant to the study; and provides empirical evidence on the association between ownership concentration and payout policies as well as between ownership concentration and tax preference. Secondly, the population, sample selection, research method, data collection, data analysis, and limitations of this study are described. Lastly, the empirical evidence (descriptive statistics and analysis of variance results) of this study is provided prior to submitting a final conclusion and suggesting areas for future research.

\section{Literature review}

Despite extensive theorising and empirical research, considerable debate continues on whether payout policy plays a role in achieving the aim to maximise investor wealth (Baker \& Weigand 2015). Dividend relevance theories have been extensively researched within major theories and explanations; these include the bird-in-the-hand, taxes and tax clienteles, signalling, agency costs, behavioural explanations, company life-cycle theory, and catering theory (Baker \& Weigand 2015). The lack of consensus on the motivations for paying dividends remains unsolved despite much research and debate (Al-Najjar \& Kilincarslan 2019). The present study is grounded in dividend relevance theories and closely related agency costs theory. Agency costs theory dates back to Jensen (1986) and suggests that companies pay dividends to align the interests of and mitigate the agency problems between managers and investors, thereby reducing the discretionary funds available to managers (Baker \& Weigand 2015). Two opposing agency-based hypotheses, the monitoring hypothesis and rent extraction hypothesis, could explain the effect of ownership concentration on dividend policy (Harada \& Nguyen 2011).

Large shareholders could reduce the agency conflict between shareholders and management. However, the concentration of large shareholders could also evoke agency problems between majority and minority shareholders (Faisal et al. 2020). Agency conflict arises because of the separation of shareholders (namely the owners of a company) and those charged with managing the company. Large shareholders can exert pressure on a company to adopt a dividend policy that reduces the private consumption by management. Large shareholders however, could also enforce a dividend policy that maximises their private benefit at the expense of minority shareholders (Truong \& Heaney 2007). Concentrated ownership could be expected to be associated with higher payout under the monitoring hypothesis, which posits that 
dividend payments reduce agency costs by removing excess cash under management control (Harada \& Nguyen 2011). The supervision by large shareholders (with an incentive and capability to control the management) could conceivably reduce the agency conflict between shareholders and management, providing a positive effect on company value (Faisal et al. 2020). On the other hand, concentrated ownership could be expected to be associated with lower payout under the rent extraction hypothesis, which posits that large shareholders prefer to extract private benefits of control rather than receive dividends that equally benefit all shareholders (Harada \& Nguyen 2011). Agency conflict between the majority and minority shareholders could elicit a negative market reaction and decrease company value if majority shareholders enjoy private benefits as a result of their control (Faisal et al. 2020). The largest shareholders that adversely affect dividend payout could negatively affect the perception of minority shareholders and discourage them from participating on the stock exchange, in turn affecting market liquidity and company value (Aluchna, Berent \& Kamiński 2019). The interaction between high ownership concentration, agency conflict, payout, and company value is illustrated in Figure 1.

\section{Defining ownership concentration and payout methods}

Ownership concentration measures most commonly found in earlier research include existing concentration measures in the economic literature and threshold measures for a controlling shareholder (Mavruk, Overland \& Sjögren 2019). For the purpose of the present study, high ownership concentration is measured in terms of the Herfindahl ownership concentration index (hereafter referred to as the Herfindahl index [HOCI]) which reflects ownership concentration based on the top five shareholders in companies (Gonzalez et al. 2017; Harada \& Nguyen 2011). Additionally, in line with earlier studies (Mavruk et al. 2019; Trinchera 2012), a controlling shareholder

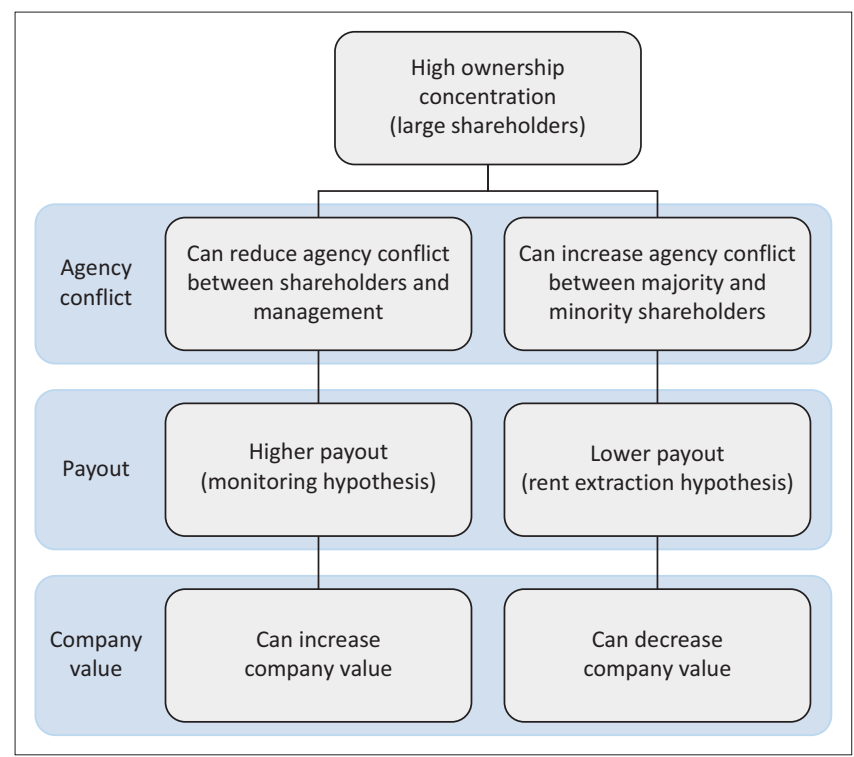

FIGURE 1: Interaction between high ownership concentration, agency conflict, payout, and company value. is defined as a shareholder who owns at least $20 \%$ of a company. This line of thought is also supported by the argument made by La Porta, Lopez-de-Silanes and Shleifer (1999) that a stake of $20 \%$ of voting rights is typically sufficient to gain effective control (Trinchera 2012). The present study assumed that percentage shareholding equates to percentage voting rights as only shareholding (and not voting rights) were considered in this study.

For the purpose of the present study, a payout method refers to a distribution as defined in terms of section 1 of the Companies Act (Republic of South Africa 2008) as well as to a dividend as defined in terms of section 1 of the Income Tax Act (Republic of South Africa 2020). The different payout methods contemplated in this study refers to dividends, capital distributions, additional shares, and share repurchases as described in Nel and Wesson (2021).

\section{Ownership concentration and payout policies}

Global findings with respect to the association between ownership concentration and payout policies predominantly provide support for the rent extraction hypothesis rather than the monitoring hypothesis. Large shareholders have been found to be associated with lower dividend payout, with only a limited number of studies showing a positive association between ownership concentration and dividend payout (Aluchna et al. 2019). Empirical evidence in support of the rent extraction hypothesis has been submitted from the context of both developed (Harada \& Nguyen 2011; Mancinelli \& Ozkan 2006) and developing countries (Besim \& Adaoglu 2018; Faisal et al. 2020; Gonzalez et al. 2017; Thanatawee 2013). Support for the monitoring hypothesis is limited in global findings (Abdullah, Ahmad \& Roslan 2012). Literature has also considered the association between ownership concentration and share repurchases - therefore not solely focusing on dividends as a payout method. Literature suggests that ownership concentration does not have a statistically significant effect on share repurchases in a developing country context (Chasiotis, Georgantopoulos \& Eriotis 2021). However, a positive association between ownership concentration by individual and family owners and share repurchase market reaction was observed in a developing country context (Dayanandan et al. 2020), which could suggest an effect of ownership concentration on share repurchases (i.e. payout other than dividends).

Ownership concentration has been identified as a potential area for further research in the South African context (Pequenino 2018). Truong and Heaney (2007) included South Africa as one of 37 countries in their study, with a target period of 2004, and found that companies are more likely to pay dividends when the largest shareholder is not an insider (such as a director or officer) and that companies tend to pay fewer dividends when the largest shareholder is either an insider or a financial institution. Abor and Fiador (2013) included South Africa in their examination of the effect of corporate governance on the dividend payout policy of firms in sub-Saharan Africa (SSA) for the period 1997 to 2006. 
Institutional ownership in South Africa was found to be statistically significantly related to the dividend payout ratio, implying that companies with a higher percentage of institutional ownership exhibit a high-dividend payout policy (Abor \& Fiador 2013). Subsequent to these early studies, significant tax reform occurred in South Africa in 2012 with the introduction of dividend tax and increases in applicable tax rates. This brought to light conflicting tax preferences of shareholders for different payout methods. Dube (2018) studied the different types of ownership in an analysis of the effect of ownership concentration on capital structure and corporate performance of South African listed companies for the period 2004 to 2014. Qopana (2018) investigated, for selected JSE-listed companies, whether ownership structure, including high ownership concentration, can mitigate agency conflicts of South African listed companies for the period 2005 to 2016. High ownership concentration was found to be statistically significant in relation to agency cost measures (Qopana 2018). Although the studies of Dube (2018) and Qopana (2018) included the period since tax reform in 2012, they did not consider the association between ownership concentration and payout methods. The opportunity was accordingly provided to investigate the association between ownership concentration and payout methods of selected JSE-listed companies in South Africa.

\section{Ownership concentration and tax preference}

Groups of shareholders who are taxed differently have different incentives for becoming informed about corporate affairs (Allen, Bernardo \& Welch 2000). The tax preference of shareholders could thus be argued to be less important in instances of diverse ownership owing to coordination problems and the conflicting objectives of owners and managers (Jacob \& Michaely 2017), or if owners with varying tax burdens engage in tax-driven trading around the exdividend day (Peyer \& Vermaelen 2016). Nonetheless, the presence of a large or dominant investor has been found to elicit specific responses by companies in cases of tax reform (Booth \& Zhou 2017; Korkeamaki, Liljeblom \& Pasternack 2010). The literature accordingly supports the principle that companies take the tax preferences of large shareholders into account when defining their payout policy (Trinchera 2012), and that the behaviour of companies around expected tax reform is explained by the ownership structure of the companies (Peyer \& Vermaelen 2016).

Higher insider ownership (by directors and officers) has been found to elicit a more notable response to taxes if the tax rate of dividends and capital gains differ (Jacob \& Jacob 2013). An increase in senior managerial share ownership and the dividend tax penalty (i.e. the difference in individual shareholder tax rates between dividend income and capital gains) could encourage companies to elect payout methods other than dividends, such as share repurchases, that are not subject to dividends tax (Moser 2007). Where institutional investors are the majority investors, a tax-based theory would merit a better argument to explain a positive association between dividend distribution and ownership concentration because of dividend preference (Short, Zhang \& Keasey 2002). Institutional investors have been found to match to companies in dividend clienteles and that companies alter dividend policy in response to the tax preferences of these institutional investors (Desai \& Jin 2011). An institutional investor's influence over dividend policy could further vary based on the extent of monitoring and the level of insider ownership (Krupa \& Utke 2019). Tax-sensitive insiders could insist on the acceleration of a payout method in order to minimise their tax liability, in which case a taxinsensitive, dedicated institutional investor could monitor the company's payout policy and prevent the payout from being distributed to the insiders (Krupa \& Utke 2019). Institutional ownership could also be relevant in considering a choice between distributing dividends and share repurchases based on the tax status of the institutions and differential tax rates of dividends and capital gains (Moser 2007). The tax preference of large shareholders (indicative of ownership concentration) could therefore be expected to affect the payout of companies. The tax reform that has an impact on the tax preferences of shareholders for payout methods could accordingly offer an opportunity to investigate the association between ownership concentration and payout methods.

Tax reform undertaken in South Africa during 2012 led to the introduction of dividends tax at shareholder-level with exemption afforded only to certain taxpayers and this affected payout methods other than dividends (Nel \& Wesson 2021). Based on the consideration of the total payout (i.e. dividends, capital distributions, additional shares, and share repurchases) of selected JSE-listed companies, an increase in the use of dividends compared to payout other than dividends was reported since 2012 (Nel \& Wesson 2021). In particular, the tax preference for different types of share repurchases has been notable, with a general repurchase by a JSE-listed company not being regarded as a dividend for tax purposes, whereas a specific repurchase by a JSE-listed company being regarded as a dividend in part (Nel \& Wesson 2021). The association between ownership concentration and payout methods has, however, not been considered in the South African context since the tax reform of 2012. The tax preference for dividends (subjected to dividends tax and affording exemption to certain shareholders) and payout other than dividends (generally subjected to capital gains tax if held with capital intent) has been notably affected by tax reform since 2012 (Nel \& Wesson 2021). This provides an opportunity to investigate the association between ownership concentration and payout methods of selected JSE-listed companies in South Africa since tax reform in 2012.

\section{Research method}

The present study was based in the positivistic paradigm on the ontological foundation that the world is viewed objectively - independent from knowledge (epistemology) and apart from the researcher (McKerchar 2008). An archival study was followed by considering historical documents and 
corporate annual reports to generate research (Smith 2020). Questions of validity are best considered in the trade-offs, inter alia, between internal validity and external validity (Smith 2020). A threat to internal validity could also arise if different definitions are used in source data or by fellow researchers (Smith 2020). This study clearly defined ownership concentration and payout methods as the two key elements of the present study. The different payout methods contemplated in this study refers to dividends, capital distributions, additional shares, and share repurchases as described in Nel and Wesson (2021). This study, as an archival study, did not aim to establish a causal relationship between payout and ownership concentration, but rather to provide descriptive evidence of the relationship between payout and ownership concentration. An archival study would, however, normally have more external validity than experimental or simulation approaches because of its reference to empirical data (Smith 2020). This study therefore asserted external validity on the basis of inference from empirical data.

Reliability establishes the consistency of the research instrument in that the result it achieves should be similar in similar circumstances (Smith 2020). This study aimed to contribute to reliability by means of detailed documentation of methods employed for data collection to enable replication in other studies. This study also relied on annual financial statements of the JSE-listed companies which are subjected to annual audits, contributing further to the reliability of data used. The databases utilised in this study (IRESS and Refinitiv Eikon) are well-known commercial databases regularly applied by researchers and in practice, which further enhances the reliability of data obtained from these databases.

\section{Population and sample selection}

The population of this study comprised JSE-listed companies with reporting periods covering the 8 years from 2012 to 2019. The study covered the period from the introduction of dividends tax in South Africa in 2012 to allow for consistent classification of different payout methods (namely dividends, capital distributions, additional shares, and share repurchases) under the dividends tax regime. Companies were selected on the basis of the following four criteria: (1) companies with listed ordinary and/or N-class shares; (2) companies with their primary listing on the JSE; (3) companies listed on the JSE main board and not in the resources and financial sectors; and (4) companies listed during the full duration of the period 2009 to 2015 (being companies listed for the 3 years before and after the introduction of dividends tax). Consequently, companies that delisted before 2009 were excluded, whereas companies that had delisted after 2015 were included in the intended population of the study in an attempt to eliminate survivorship bias (De Vries et al. 2012; Mans-Kemp \& Viviers 2015).

In terms of the Industry Classification Benchmark, the JSElisted companies are classified into three sectors, namely resources, financial and industrial (Nyere \& Wesson 2019). The resources sector comprises oil and gas producers and mining companies. The financial sector comprises companies operating in the financial industry. The industrial sector comprises companies in the remaining Industry Classification Benchmark sub-sectors of industrial, consumer goods, healthcare, consumer services, telecommunications, utilities, and technology industries. Companies listed in the resources and financial sectors were excluded owing to unique accounting policies regarding capital investments and financing (Wesson et al. 2018). Companies in the resources sector also generally follow commodity prices rather than company-specific factors, whereas the financial sector companies are highly regulated and have capital structures with high, but acceptable, debt levels (Bester 2008). As a result of sector-specific differences, the factors influencing the dividend payout of industrial sector companies were likely to be different from those of the resources and financial sectors (Nyere \& Wesson 2019). Consequently, companies in the resources and financial sectors were excluded from the sample used in the present study.

This study accordingly employed the same population as Nel and Wesson (2021), who studied the trend and composition of payout methods over a period of tax reform, in order to expand on their findings by including the 2019 financial year of companies and investigating the association between ownership concentration and payout methods. In total, 116 companies were included in the population, comprising 33 large companies, 43 medium-sized companies, and 40 small companies based on market capitalisation during 2012. The company size classifications (small, medium, and large) of the JSE during 2012 were applied, namely large companies represented by companies with a market capitalisation exceeding R10 bn; medium size companies with market capitalisation exceeding R1 bn but not exceeding R10 bn; and small companies with market capitalisation of R1 bn or less (SA Shares 2019).

From the total observations of payout methods for companies, a sample was selected based on three areas of exclusion: (1) the exclusion of observations with a zero value for a payout method (therefore a payout method not elected or distributed); (2) the exclusion of special dividend observations because of unbundling; and (3) the exclusion of dividend observations that were cancelled during 2019 as a result of the coronavirus disease 2019 (COVID-19) pandemic. The focus on observations of the payout method that occurred allowed inferences to be made about the association between ownership concentration and payout methods. Observations with a zero value for a payout method were only considered to a limited extent in the present study by means of a comparison between the number of observations for each payout method based on a distinction between low and high ownership concentration. Special dividends as a result of unbundling were excluded on the basis of commercial reasoning and specific tax relief which would negate an argument in favour of ownership concentration. The commercial reasons for special dividends could be the result 
of large restructurings or divestments by companies (Bird 2013) and specific tax relief in terms of section 46 of the Income Tax Act (Republic of South Africa 2020). The 2019 dividend observations of companies that disclosed - either in their financial statements or via the Security Exchange News Service (SENS) - that dividends were reduced or deferred in terms of a regulatory allowance related to the COVID-19 pandemic (JSE 2020a, 2020b) were also excluded from the data analysis.

\section{Data collection}

\section{Payout methods}

Payout methods comprise dividends (ordinary and special), capital distributions, additional shares, and share repurchases (general and specific), as described by Nel and Wesson (2021). Dividends (ordinary and special) are distributions from retained earnings. Capital distributions are the portion of dividends reflected as a reduction in share capital, share premium, or stated capital which are not the result of a share repurchase. Additional shares are the increase in share capital, share premium, or stated capital, if the shares were issued at no consideration (with a bonus issue serving as an example). Share repurchases (general and specific) represent a reduction in retained earnings, share capital, share premium, or stated capital. General (or open market) share repurchases represent shares repurchased in the open market and specific share repurchases represent pro-rata (or tender) offers and other specific (or private) offers (Wesson, Bruwer \& Hamman 2015).

The present study made use of data on total payout from the research of Nel and Wesson (2021), which consisted of the expansion and consolidation of an existing dividend database (Nyere \& Wesson 2019), and a share repurchase database (Steenkamp \& Wesson 2020). This study expanded on the database of Nel and Wesson (2021) by including the payout methods of selected companies for the 2019 financial years and incorporating ownership concentration variables (described in the section which follows). In line with the data collection method described in Nel and Wesson (2021), payout data were collected from disclosed annual financial statements and announcements via SENS.

Payout methods were measured in value and number of observations. Payout values in South African rand were represented in 2012 terms by applying the deflation factors calculated from the consumer price index(CPI) published by Statistics South Africa (2019).

\section{Ownership concentration dummy variables}

Two ownership concentration dummy variables were considered in the present study, being the HOCI and controlling shareholder, both of which are based on shareholding data. Shareholding data of companies were obtained from shareholder history reports from the Refinitiv database (previously Thomson Reuters). Refinitiv has more than 30 years of experience and maintains the most complete global share ownership profiles data in the industry (Refinitiv 2020).
The HOCI is calculated per company as the square of percentage shareholding held by the top five shareholders (Harada \& Nguyen 2011). Despite not reflecting the relative voting power of shareholders, the HOCI succeeds in capturing the dispersion of ownership across shareholders and the relative power of a group of shareholders (Goergen \& Renneboog 2001). High ownership concentration observations are those whose HOCI is above the median value of the index for all companies (Arora \& Srivastava 2019). Low ownership concentration observations are those whose HOCI is below the median value of the index for all companies (Arora \& Srivastava 2019). For each companyyear observation, the HOCI was calculated per company as the square of percentage shareholding held by the top five shareholders (Harada \& Nguyen 2011). A binary variable was applied to indicate observations with high ownership concentration (as ' 1 ') and low ownership concentration (as ' 0 '). A controlling shareholder is one that has a shareholding of at least $20 \%$ in a company (Mavruk et al. 2019). A binary variable was applied to indicate observations with a controlling shareholder (as ' 1 ') and observations with no controlling shareholder (as ' 0 ').

\section{Data analysis}

This study employed descriptive statistics to describe the total payout in value and per number of observations for low and high ownership concentration. A mixed model analysis of variance (ANOVA) was performed using TIBCO Statistica 13.5 to investigate the variance between high ownership concentration observations $(\mathrm{HOCI}=1)$ and low ownership concentration observations $(\mathrm{HOCI}=0)$ for each of the payout methods. Box-Cox transformation was applied to all payout method variables. Box-Cox transformation represents a potential best practice, where normalising data or equalising variance is desired and which incorporates, extends, and improves on traditional normalising approaches (Osborne 2010). In addition, the Kenward-Roger degrees of freedom was applied in the mixed-model ANOVA. The significance of results was evaluated using $F$-statistics and the calculated probability ( $p$-value), and significance was interpreted at the $90 \%, 95 \%$, and $99 \%$ confidence intervals.

\section{Limitations of the present study}

The present study made inferences based on the sign of coefficients and the significance levels that resulted from the mixed model ANOVA in investigating support for the rent extraction hypothesis or monitoring hypothesis. Consequently, this study neither made inferences based on the value of coefficients, nor based on the rand value increases or decreases in payout methods.

In respect of the rent extraction hypothesis, a conceivable interaction between controlling shareholders (tasked with appointing directors) and directors is acknowledged - in which directors would only be guilty of rent extraction if payout exceeds the payout of directors in comparable companies. This study did not include consideration of the 
interaction between controlling shareholders and directors in investigating support for the rent extraction hypothesis.

This study was descriptive in nature and only considered the association between ownership concentration and payout methods. Other determinants of payout methods were not considered in this study (including company growth and company value) and could serve as an avenue for further explanatory research. Investors could, for instance, acquire shares in a company with a perceived durable competitive advantage, without expecting high dividend payments (Buffett \& Clarke 2002). Company growth and company value could be included as determinants in further empirical research relating to ownership concentration and payout methods.

\section{Descriptive statistics}

The total payout data collected (in real terms) amounted to R724.2 bn for the period 2012 to 2019 and the composition, illustrated in Figure 2, depicts the contribution of each payout method to the total payout. Ordinary dividends constituted the overwhelming majority of total payout and together with special dividends represented $88.66 \%$ of the total payout. Share repurchases (general and specific) represented the second-highest payout method in value. However, they constituted less than $10 \%$ of the total payout (being $9.67 \%$ ). Capital distributions and additional shares contributed the least to the total payout. Based on the total payout, ordinary dividends were the most preferred payout method in value.

Payout methods in value were Box-Cox transformed to investigate the association with ownership concentration. The descriptive statistics of transformed variables are provided in Table 1. Based on the number of observations, ordinary dividends $(n=656)$ and general share repurchases $(n=243)$ were the most frequent of all payout methods regardless of a distinction between low and high ownership concentration. The number of observations with respect to high ownership concentration $(n=474)$ was lower than that of low ownership concentration $(n=565)$ for all payout methods apart from special dividends and capital

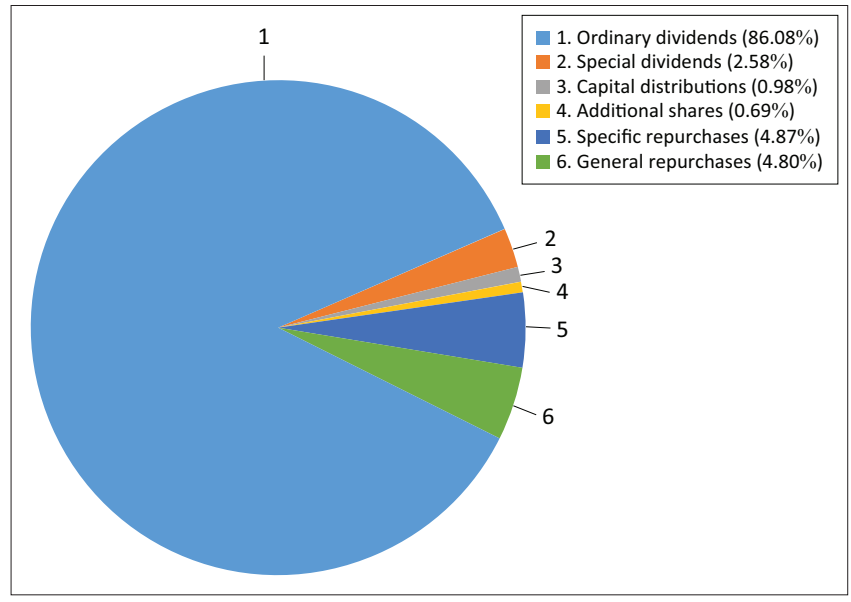

Source: Payout methods from Nel and Wesson (2021) expanded to include data from the 2019 financial year of companies

FIGURE 2: Composition of total payout (in real terms) from 2012 to 2019. distributions. Based on the number of observations, the two main payout methods (i.e. ordinary dividends and general share repurchases) showed the most notable lower payout in respect of high ownership concentration observations. This finding suggests that, based on the number of observations for the two payout methods selected most frequently, high ownership concentration is associated with a lower payout and supports the rent extraction hypothesis. An analysis of variances of payout methods on rand values follows in the following section.

\section{Analysis of variance results}

The ANOVA results on high ownership concentration observations $(\mathrm{HOCI}=1)$ and low ownership concentration observations $(\mathrm{HOCI}=0)$ for each of the respective payout methods in rand value are provided in Table 2 and graphically displayed in Figure 3.

High ownership concentration was found to be associated with statistically significantly lower ordinary dividends and capital distributions (Figure 3). The finding of significantly lower dividends in cases of high ownership concentration is in line with the lower number of ordinary dividend observations associated with high ownership concentration reported in Table 1. High ownership concentration observations were noted to have more instances of electing capital distributions (Table 1). However, capital distributions in value were found to be statistically significantly lower in value in respect of high ownership concentration observations (Figure 3). This finding suggests that, although there were more high ownership concentration observations for capital distributions, the value of those capital distributions was

TABLE 1: Descriptive statistics of different payout methods.

\begin{tabular}{lcccccccc}
\hline Payout method & \multicolumn{3}{l}{ Low ownership concentration } & & \multicolumn{3}{l}{ High ownership concentration } \\
\cline { 2 - 5 } \cline { 7 - 8 } & $N$ & Mean & $\begin{array}{c}\text { Standard } \\
\text { deviation }\end{array}$ & & & & Mean & $\begin{array}{c}\text { Standard } \\
\text { deviation }\end{array}$ \\
\hline Ordinary dividends & 351 & 34.95 & 5.87 & & 305 & 31.74 & 5.43 \\
Special dividends & 7 & 81.29 & 5.23 & 17 & 73.00 & 17.85 \\
Capital distributions & 11 & 11.43 & 0.21 & 13 & 10.53 & 0.50 \\
Additional shares & 8 & 108.04 & 30.79 & 4 & 123.67 & 35.62 \\
Specific repurchases & 49 & 51.91 & 17.99 & 31 & 54.44 & 13.97 \\
General repurchases & 139 & 44.42 & 9.68 & 104 & 41.69 & 9.59 \\
\hline
\end{tabular}

Note: A distinction is made between low and high ownership concentration observations to enable a comparison. The number of observations $(N)$, mean, and standard deviation of each payout method (Box-Cox transformed) are presented as descriptive statistics. The total number of observations was 565 in respect of low ownership concentration and 474 in respect of high ownership concentration.

TABLE 2: Analysis of variance of payout methods (High ownership concentration).

\begin{tabular}{lcccc}
\hline Payout method & Mean square & $\begin{array}{c}\text { Degrees of } \\
\text { freedom }\end{array}$ & $\boldsymbol{F}$ & $\boldsymbol{p}$ \\
\hline Ordinary dividends & 59.77 & 575 & 21.58 & $<0.01^{* * *}$ \\
Special dividends & 0.15 & 13 & 0.05 & 0.83 \\
Capital distributions & 0.22 & 11 & 7.09 & $0.02^{* *}$ \\
Additional shares & 67.17 & 5 & 0.11 & 0.76 \\
Specific repurchases & 56.83 & 55 & 0.53 & 0.47 \\
General repurchases & 29.14 & 227 & 0.81 & 0.37 \\
\hline
\end{tabular}

Note: An analysis of variance between low ownership concentration observations and high ownership concentration observations for each of the respective payout methods (Box-Cox transformed).

**, $p<0.05 ; * * *, p<0.01$. 


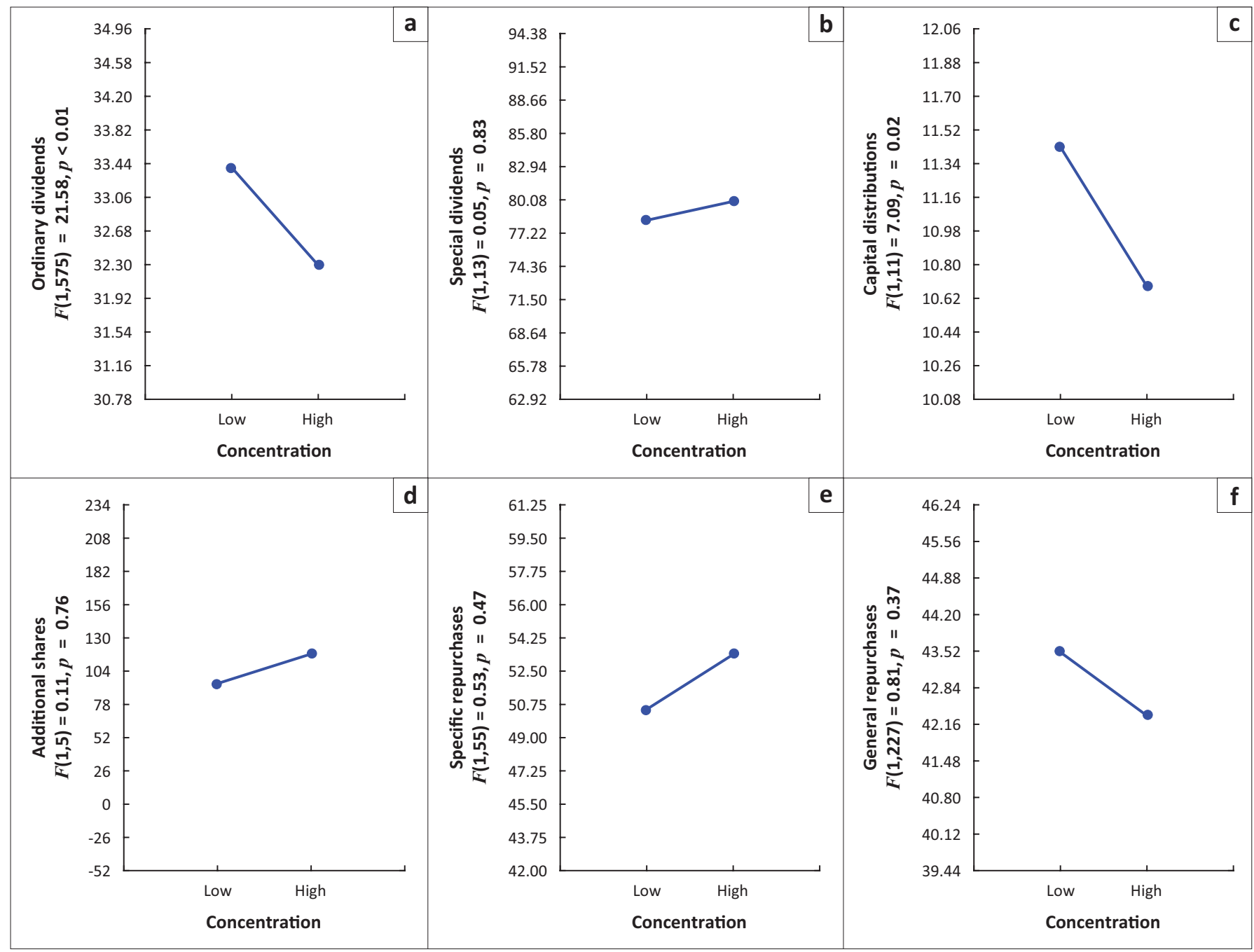

FIGURE 3: Comparison of payout behaviour for low and high ownership concentration.

TABLE 3: Analysis of variance of payout methods (Controlling shareholder).

\begin{tabular}{lcccc}
\hline Payout method & Mean square & $\begin{array}{c}\text { Degrees of } \\
\text { freedom }\end{array}$ & $\boldsymbol{F}$ & $\boldsymbol{p}$ \\
\hline Ordinary dividends & 46.59 & 583 & 16.77 & $<0.01^{* * *}$ \\
Specific repurchases & 86.56 & 63 & 0.78 & 0.38 \\
General repurchases & 18.23 & 227 & 0.52 & 0.47 \\
\hline
\end{tabular}

Note: An analysis of variance between observations with no controlling shareholder and observations with a controlling shareholder for each of the respective payout methods (BoxCox transformed). An analysis of variance in respect of special dividends, capital distributions, and additional shares was not possible because of an insufficient number of observations based on the grouping dummy variable.

$* * *, p<0.01$.

lower than in the case of low ownership concentration observations. Despite not being statistically significant, high ownership concentration observations were also found to be associated with lower general repurchases (Table 1, Figure 3). Overall, high ownership concentration was observed as being associated with a statistically significant lower payout for ordinary dividends and capital distributions, with these two payout methods representing the overwhelming majority $(87.06 \%)$ of total payout in value (Figure 2 ). High ownership concentration is accordingly submitted as being associated with a lower payout in support of the rent extraction hypothesis. These findings suggest support for the rent extraction hypothesis in respect of payout policies, which is in line with previous literature from other developing countries (Besim \& Adaoglu 2018; Faisal et al. 2020; Gonzalez et al. 2017; Thanatawee 2013). The results in respect of rent extraction relating to ordinary dividends are further supported based on considering a controlling shareholder (Table 3) which emphasises the potential role of a controlling shareholder in relation to ownership concentration and payout.

The positive association between high ownership concentration observations and special dividends, additional shares, and specific repurchases was found not to differ statistically significantly from low ownership concentration observations. The observable differences in respect of special dividends and additional shares were also the least pronounced, as reflected in Figure 3. Furthermore, special dividends, additional shares, and specific repurchases contributed only $8.14 \%$ to the total payout in value (Figure 2). The findings on marginally higher special dividends, additional shares, and specific repurchases are therefore not submitted as being in contradiction to the findings of the present study in support of the rent extraction hypothesis.

The inverse association observed on comparing the results of specific repurchases and general repurchases (Figure 3) 
suggests that companies with high ownership concentration preferred, on the basis of values, entering into specific repurchases rather than general repurchases. This observation, despite not being found as statistically significant, reveals potential agency conflicts and tax preferences. Specific repurchases are mainly represented by other specific offers (private offers to specific shareholders) rather than pro-rata offers (tender offers to all shareholders) in South Africa (Steenkamp \& Wesson 2020). High ownership concentration is accordingly associated with share repurchases from identified shareholders (other specific offers) rather than from all shareholders (pro-rata offers and general repurchases), which portrays the agency conflict between majority and minority shareholders. Based on tax preferences, high ownership concentration was found to be associated with higher specific repurchases (subjected to dividends tax and affording exemption to certain shareholders) and lower general repurchases (not subjected to dividends tax), which could indicate a tax preference for payout subjected to dividends tax. The present study did not consider the identity of major shareholders and their tax preferences which could be further investigated in future research.

\section{Conclusion}

The effect of ownership concentration on dividend policy has been considered in the literature under two opposing hypotheses, the monitoring hypothesis, and the rent extraction hypothesis. This study contributes to the literature in that it is the first study to investigate the association between ownership concentration and different payout methods, namely ordinary dividends, special dividends, capital distributions, additional shares, specific repurchases, and general repurchases, in the South African context. Tax reform instituted in South Africa in 2012 provided a distinct setting for empirical investigation.

The study considered whether payout methods of the selected JSE-listed companies for the period 2012 to 2019 differed when low and high ownership concentration is compared. Ordinary dividends and capital distributions were found to be statistically significantly lower for observations with high ownership concentration. These findings suggest support for the rent extraction hypothesis in line with previous literature from other developing countries (Besim \& Adaoglu 2018; Faisal et al. 2020; Gonzalez et al. 2017; Thanatawee 2013). Findings also suggest that observations with high ownership concentration are associated with higher specific repurchases (and lower general repurchases), which reveals the potential agency conflict between majority and minority shareholders, as well as the tax preference. The policy implication is that the agency conflicts mentioned could be informative regarding the supervisory responsibilities of shareholders, regulators, and other market participants, and help to prevent and reduce such agency conflicts (Faisal et al. 2020).
The descriptive findings of this study suggest support for the rent extraction hypothesis based on an ANOVA. Further empirical research could provide explanatory evidence based on multivariate statistics, as was done by Harada and Nguyen (2011). Future research could consider the identity of major shareholders and their tax preferences to provide further insights into the association between tax, ownership concentration, company value, company growth, and payout behaviour.

\section{Acknowledgements}

We would like to acknowledge and thank Prof. Martin Kidd (Centre for Statistical Consultation, Stellenbosch University) for the statistical analyses performed with respect to this study.

\section{Competing interests}

The authors declare that they have no financial or personal relationships that may have inappropriately influenced them in writing this article.

\section{Authors' contributions}

R.N. was the primary researcher as part of his PhD study. N.W. and L.-A.S. supervised the research project in capacity as $\mathrm{PhD}$ supervisors.

\section{Ethical considerations}

The Departmental Ethics Screening Committee of the University of Stellenbosch Business School (USB DESC) reviewed the application for the above-mentioned research. The research as set out in the application is confirmed as exempt from ethical clearance, reference number: USB-2019-9637.

\section{Funding information}

This research received no specific grant from any funding agency in the public, commercial or not-for-profit sectors.

\section{Data availability}

The data that support the findings of this study are available from the corresponding author, R.N., upon reasonable request.

\section{Disclaimer}

The views and opinions expressed in this article are those of the authors and do not necessarily reflect the official policy or position of any affiliated agency of the authors.

\section{References}

Abdullah, N.M.H., Ahmad, Z. \& Roslan, S., 2012, 'The influence of ownership structure on the firms dividend policy based Lintner model', International Review of Business Research Papers 8(6), 71-88.

Abor, J. \& Fiador, V., 2013, 'Does corporate governance explain dividend policy in SubSaharan Africa?', International Journal of Law and Management 55(3), 201-225. https://doi.org/10.1108/17542431311327637 
Allen, F., Bernardo, A.E. \& Welch, I., 2000, 'A theory of dividends based on tax clienteles', The Journal of Finance 55(6), 2499-2536. https://doi.org/10.1111/0022-1082.00298

Al-Najjar, B. \& Kilincarslan, E., 2019, 'What do we know about the dividend puzzle? -A literature survey', International Journal of Managerial Finance 15(2), 205-235. https://doi.org/10.1108/IJMF-03-2018-0090

Aluchna, M., Berent, T. \& Kamiński, B., 2019, 'Dividend payouts and shareholder structure: Evidence from the Warsaw Stock Exchange', Eastern Europea Economics 57(3), 227-250. https://doi.org/10.1080/00128775.2019.1568196

Arora, R.K. \& Srivastava, A., 2019, 'Ownership concentration and dividend payout in emerging markets: Evidence from India', Global Business Review, 1-13. https:// doi.org/10.1177/0972150918824953

Baker, H.K. \& Weigand, R., 2015, 'Corporate dividend policy revisited', Managerial Finance 41(2), 126-144. https://doi.org/10.1108/MF-03-2014-0077

Besim, S. \& Adaoglu, C., 2018, 'Dividend payouts: Majority control and rent extraction' Journal of Business Economics and Management 19(4), 648-672. https://doi. org/10.3846/jbem.2018.6808

Bester, P.G., 2008, 'Shareholder distribution choices for industrial companies listed on the JSE: Share buybacks versus dividends', Master's thesis, Stellenbosch University.

Bird, A., 2013, 'Dividends and shareholder taxation: Evidence from Canada', unpublished paper, Carnegie Mellon University, Tepper School of Business.

Booth, L. \& Zhou, J., 2017, 'Dividend policy: A selective review of results from around the world', Global Finance Journal 34, 1-15. https://doi.org/10.1016/j. gfj.2017.07.002

Buffett, M. \& Clark, D., 2002, The New Buffettology, Rawson Associates, New York.

Chasiotis, I., Georgantopoulos, G.A. \& Eriotis, N., 2021, 'Determinants of share repurchases: A quantile regression approach', Economics and Business Letters 10(1), 27-36. https://ssrn.com/abstract=3791379

Dayanandan, A., Donker, H., Kuntluru, S. \& Nofsinger, J., 2020, 'Share buybacks in India', Research in International Business and Finance 54, 1-11. https://doi. org/10.1016/j.ribaf.2020.101296

Desai, M.A. \& Jin, L., 2011, 'Institutional tax clienteles and payout policy', Journal of Financial Economics 100(1), 68-84. https://doi.org/10.1016/j.jfineco.2010.10.013

De Vries, A., Erasmus, P.D., Hamman, W.D. \& Wesson, N., 2012, 'The effect of specific share repurchases on South African payout ratios: An exploratory study', Risk Governance and Control: Financial Markets and Institutions 2(31), 7-16. https:// Governance and Control: Fina

Dube, T., 2018, 'An analysis of effects of ownership on capital structure and corporate performance of South African companies', PhD dissertation, University of Pretoria, viewed from http://hdl.handle.net/2263/67994

Faisal, F., Majid, M.S.A. \& Sakir, A., 2020, 'Agency conflicts, firm value, and monitoring mechanisms: An empirical evidence from Indonesia', Cogent Economics Finance 8(1), 1822018. https://doi.org/10.1080/23322039.2020.1822018

Feito-Ruiz, I., Renneboog, L. \& Vansteenkiste, C., 2020, 'Elective stock and scrip dividends', Journal of Corporate Finance 64, 101660. https://doi.org/10.1016/j jcorpfin.2020.101660

Goergen, M. \& Renneboog, L., 2001, 'Investment policy, internal financing and ownership concentration in the UK', Journal of Corporate Finance 7(3), 257-284. https://doi.org/10.1016/S0929-1199(01)00022-0

Gonzalez, M., Molina, C.A., Pablo, E. \& Rosso, J.W., 2017, 'The effect of ownership concentration and composition on dividends: Evidence from Latin America', Emerging Markets Review30,1-18. https://doi.org/10.1016/j.ememar.2016.08.018

Harada, K. \& Nguyen, P., 2011, 'Ownership concentration and dividend policy in Japan', ManagerialFinance37(4),362-379.https://doi.org/10.1108/03074351111115313

Jacob, M. \& Jacob, M., 2013, 'Taxation, dividends, and share repurchases: Taking evidence global', Journal of Financial and Quantitative Analysis 48(4), 1241-1269. https://www.jstor.org/stable/43303839

Jacob, M. \& Michaely, R, 2017, 'Taxation and dividend policy: The muting effect of agency issues and shareholder conflicts', The Review of Financial Studies 30(9), 3176-3222. https://doi.org/10.1093/rfs/hhx041

Jensen, M.C., 1986, 'Agency costs of free cash flow, corporate finance and takeovers', American Economic Review 76(2), 323-329.

Johannesburg Stock Exchange (JSE), 2020a, 'COVID-19: Cancellation, changes and postponement of payment of dividends after declaration date', JSE Letter, 30 March 2020.

Johannesburg Stock Exchange (JSE), 2020b, 'COVID-19: Payments of dividends', JSE Letter, 02 April 2020

Korkeamaki, T., Liljeblom, E. \& Pasternack, D., 2010, 'Tax reform and payout policy: Do shareholder clienteles or payout policy adjust?', Journal of Corporate Finance 16(4), 572-587. https://doi.org/10.1016/j.jcorpfin.2009.12.003

Krupa, T. \& Utke, S., 2019, Whose taxes matter? The effects of institutional ownership on dividend payout policy around tax rate changes, SSRN Working Paper. https:// doi.org/10.2139/ssrn.3271931

La Porta, R., Lopez-de-Silanes, F. \& Shleifer, A., 1999, 'Corporate ownership around the world', The Journal of Finance 54(2), 471-517. https://doi.org/10.1111/00221082.00115

Lazonick, W., 2014, 'Profits without prosperity', Harvard Business Review 92(9), 46-55.

Liu, J.C., Chiou, J.J. \& Yang, C.C., 2014, 'Payout policy in Taiwan: Cash dividends, stock repurchases and capital reduction', Review of Securities and Futures Markets 26(3), 47-96. https://doi.org/10.2139/ssrn.2140337
Mancinelli, L. \& Ozkan, A., 2006, 'Ownership structure and dividend policy: Evidence from Italian firms', European Journal of Finance 12(03), 265-282. https://doi. org/10.1080/13518470500249365

Mans-Kemp, N. \& Viviers, S., 2015, 'The relationship between corporate governance and dividend payout ratios: A South African study', Management Dynamics: Journal of the Southern African Institute for Management Scientists 24(2), 20-35, viewed 20 May 2021, from https://hdl.handle.net/10520/EJC174652.

Marcus, M. \& Toerien, F., 2014, 'The relative cost of internal vs. external equity in South Africa: The impact of capital gains and dividend taxes', South African Journal of Accounting Research 28(1), 97-116. https://doi.org/10.1080/10291954.2014.1 1463129

Mavruk, T., Overland, C. \& Sjögren, S., 2019, 'Keeping it real or keeping it simple? Ownership concentration measures compared', European Financial Management 26(4), 958-1005. https://doi.org/10.1111/eufm.12249

McKerchar, M., 2008, 'Philosophical paradigms, inquiry strategies and knowledge claims: Applying the principles of research design and conduct to taxation Ejournal of Tax Research 6(1), 5-22.

Moloi, T., Nharo, T. \& Hlobo, M., 2021, 'The relationship between board characteristics and dividend payment policies: The JSE Top 40 listed companies cases', Journal of Academic Finance 12(1), 30-52.

Moser, W.J., 2007, 'The effect of shareholder taxes on corporate payout choice', Journal of Financial and Quantitative Analysis 42(4), 991-1019. https://doi. org/10.1017/S0022109000003471

Nel, R. \& Wesson, N., 2021, 'The trend and composition of payout methods over a period of tax reform: Evidence from JSE-listed companies', Acta Commercii 21(1), 1-11. https://doi.org/10.4102/ac.v21i1.882

Nyere, L. \& Wesson, N., 2019, 'Factors influencing dividend payout decisions: Evidence from South Africa', South African Journal of Business Management 50(1), 1-16, viewed 20 May 2021, from https://hdl.handle.net/10520/EJC-170f44070e.

Osborne, J., 2010, 'Improving your data transformations: Applying the Box-Cox transformation', Practical Assessment, Research, and Evaluation 15(12), 1-9. https://doi.org/10.7275/qbpc-gk17

Pequenino, D.A., 2018, 'Broad-based black economic empowerment ownership deals and their impact on dividend policy: An empirical study', Master's thesis, University of the Witwatersrand, viewed 20 May 2021, from https://hdl.handle. net/10539/26798.

Peyer, U. \& Vermaelen, T., 2016, 'Political affiliation and dividend tax avoidance: Evidence from the 2013 fiscal cliff', Journal of Empirical Finance 35, 136-149. https://doi.org/10.1016/j.jempfin.2015.10.009

Refinitiv, 2020, Ownership profiles factsheet, viewed 28 January 2021, from https:// www.refinitiv.com/content/dam/marketing/en_us/documents/fact-sheets/ ownership-profiles-fact-sheet.pdf

Qopana, N.E., 2018, 'Investigation of dividend policy, corporate governance and agency costs on the Johannesburg stock exchange', Master's thesis, University of the Witwatersrand, viewed 20 May 2021, from https://hdl.handle. net/10539/29978.

Republic of South Africa, 2008, Companies Act No 71 of 2008, Government Printer, Pretoria.

Republic of South Africa, 2020, Income Tax Act No 58 of 1962, Government Printer Pretoria.

SA Shares, 2019, Defining mid cap, viewed 20 May 2021, from https://sashares.co.za/ mid-cap-jse-index

Short, H., Zhang, H. \& Keasey, K., 2002, 'The link between dividend policy and institutional ownership', Journal of Corporate Finance 8(2), 105-122. https://doi. org/10.1016/S0929-1199(01)00030-X

Smith, M., 2020, Research methods in accounting, 5th edn., Sage, London.

Statistics South Africa, 2019, CPI history, viewed 28 January 2021, from http://www. statssa.gov.za/publications/P0141/CPIHistory.pdf?

Steenkamp, G. \& Wesson, N., 2020, 'Post-recession share repurchase behaviour by JSE-listed companies: Transparent or not?', Journal of Accounting in Emerging Economies 10(3), 465-486. https://doi.org/10.1108/JAEE-02-2020-0040

Steyn, B., 2018, 'The board of directors as a governance mechanism in South Africa: An agency theory perspective', PhD dissertation, University of Kwazulu-Natal.

Thanatawee, Y., 2013, 'Ownership structure and dividend policy: Evidence from Thailand', International Journal of Economics and Finance 5(1), 121-132. https:// doi.org/10.2139/ssrn.2138186

Trinchera, O., 2012, 'Large blockholders, shareholder protection and taxes: Their impact on firm performance and payout policy', PhD dissertation, Technische Universität München, viewed 20 May 2021, from http://mediatum.ub.tum. de/?id=1097228.

Truong, T. \& Heaney, R., 2007, 'Largest shareholder and dividend policy around the world', The Quarterly Review of Economics and Finance 47(5), 667-687. https:// doi.org/10.1016/j.qref.2007.09.002

Wesson, N., Bruwer, B.W. \& Hamman, W.D., 2015, 'Share repurchase and dividend payout behaviour: The South African experience, south African Journal of Business Management 46(3), 43-54, viewed 20 May 2021, from https://hdl.handle. net/10520/EJC177659.

Wesson, N., Smit, E., Kidd, M. \& Hamman, W.D., 2018, 'Determinants of the choice between share repurchases and dividend payments', Research in International Business and Finance 45, 180-196. https://doi.org/10.1016/j.ribaf.2017.07.150 